\title{
DNA breakage induced by piceatannol and copper(II): Mechanism and anticancer properties
}

\author{
ZHENSHENG LI $^{1 *}$, XIAOZHAN YANG ${ }^{2,4 *}$, SHIWU DONG ${ }^{3}$ and XIAOHUI $\mathrm{LI}^{4}$ \\ ${ }^{1}$ College of Biomedical Engineering and Medical Imaging, Third Military Medical University, Chongqing 400038; \\ ${ }^{2}$ School of Optoelectronic Information, Chongqing University of Technology, Chongqing 400054; \\ ${ }^{3}$ College of Basic Medical Sciences, and ${ }^{4}$ Institute of Materia Medica, College of Pharmacy, \\ Third Military Medical University, Chongqing 400038, P.R. China
}

Received October 17, 2011; Accepted January 26, 2012

DOI: $10.3892 / 01.2012 .597$

\begin{abstract}
Piceatannol (3,3',4,5'-tetrahydroxy-trans-stilbene; Pice), found in a variety of plant sources including grapes, red wine, peanuts and rhubarb, is known as a metabolite and analog of Resveratrol (3,5,4'-trihydroxy-trans-stilbene; Res) and has higher bioactivity than Res. To explore the mechanism of DNA damage induced by Pice in the presence of copper $(\mathrm{Cu})$ (II), gel electrophoresis, UV-visible spectroscopy, fluorescence spectroscopy and Fourier transform infrared spectroscopy were used. The results of gel electrophoresis demonstrated that the hydroxyl radical played a critical role in DNA cleavage. Spectroscopy confirmed that the mechanism of DNA cleavage induced by Pice-Cu(II) involves the Haber Weiss and Fenton reactions. Pice chelates with $\mathrm{Cu}(\mathrm{II})$ as a bidentate ligand, and the Pice- $\mathrm{Cu}$ (II) complex undergoes intramolecular electron transfer to form the semiquinone radical anion and $\mathrm{Cu}(\mathrm{I})$, which may be reoxidated by $\mathrm{O}_{2}$ to form $\mathrm{Cu}$ (II) with hydroxyl radical generation. In brief, the formation of the hydroxyl radical and the $\mathrm{Cu}(\mathrm{II}) / \mathrm{Cu}(\mathrm{I})$ redox cycle play a key role in inducing DNA damage. In this process, Pice demonstrated pro-oxidant properties. Oxidative product(s) of Pice, semiquinone, was formed and $\mathrm{Cu}(\mathrm{I})$ was reoxidized to $\mathrm{Cu}(\mathrm{II})$. The redox cycling of copper generated reactive oxygen species, which induced DNA cleavage, the hallmark of cell apoptosis. The mechanism of DNA breakage induced by Pice-Cu(II) may be a significant pathway through which cancer cells are killed.
\end{abstract}

\section{Introduction}

Findings of previous studies showed that the antioxidant properties of plant polyphenols may not fully account for their

Correspondence to: Professor Xiaohui Li, Third Military Medical University, Chongqing 400038, P.R. China

E-mail:1zsyxz@126.com

*Contributed equally

Key words: piceatannol, anticancer, pro-oxidant, polyphenols, copper chemopreventive and anticancer effects. It has been suggested that the cytotoxic activity of plant polyphenols, at least in vitro, may be related to their pro-oxidant activity $(1,2)$. The majority of plant polyphenols possess both antioxidant and pro-oxidant activity. Several studies have also documented that plant polyphenol, a well-known antioxidant, exhibits pro-oxidant properties in vitro, particularly in the presence of transition metal ions such as copper (3-6), which accelerates lipid peroxidation and induces oxidative DNA damage.

Copper is an essential microelement in chromatin and is closely associated with bases of DNA; it is also one of the most redox-active metal ions present in cells (7). The concentration of copper has been found to be much higher in cancer cells than in normal cells (8), and the endogenous copper ions could be mobilized easily by polyphenols and the consequent pro-oxidant action (7). Therefore, Hadi et al proposed that the pro-oxidant action of polyphenolics would be an important mechanism underlying their anticancer and apoptosis-inducing properties and a better explanation for the anticancer effect of polyphenols as well as the preferential cytotoxicity towards cancer cells (9).

Resveratrol (3,5,4'-trihydroxy-trans-stilbene; Res) has been reported to have both anticarcinogenic and cardioprotective activity, which is mainly due to its antioxidant and anticoagulant properties (10-13). It is also involved in the inhibition of tumor initiation, promotion and progression. Previous reports on Res indicate that it may have a relatively low bioavailability due to its biotransformation and rapid elimination (14-16). Piceatannol (3,3',4,5'-tetrahydroxy-trans-stilbene; Pice) was first isolated from the seeds of Euphorbia lagascae (17), and is found in a variety of plant sources including grapes, red wine, peanuts, sugar cane and rhubarb (18-21). As with Res, Pice has been reported to have various pharmacological properties including anti-inflammatory $(22,23)$ and immunosuppressive features, and is a promising chemopreventive agent with anticancer activity against various tumors $(24,25)$.

Res is known to metabolize to Pice via specific human cytochrome P450 (CYP) enzymes, including CYP1A1, CYP1A2 and CYP1B1, which are overexpressed in a wide variety of human tumors $(26,27)$. Thus, Res acts as a pro-drug and Res-hydroxylated derivative Pice is a compound responsible for the biological activity against tumors. In addition, 
due to the presence of ortho-dihydroxy, Pice exhibits a better biological activity than Res (28). However, detailed information regarding the properties of Pice remains largely unknown. If pro-drugs are converted to biologically 'active metabolites' by cytochrome P450 enzymes (P450s) during the drug development process, it is essential to study the properties of Pice to establish its efficacy, toxic effect, pharmacokinetics and anticancer mechanism in particular.

A growing number of studies have focused on molecules that may bind genetic materials, such as DNA $(29,30)$. There has been an increasing demand for the investigation of DNA-targeting molecules and the mechanism of their activity towards DNA, and special attention has been paid to the intercalating agents as a class of anti-tumor compounds $(31,32)$.

In this study, we investigated the mechanism of the Pice$\mathrm{Cu}$ (II) reaction. In this reaction, $\mathrm{Cu}$ (II) was reduced to $\mathrm{Cu}$ (I) by Pice with the concomitant formation of reactive oxygen species (ROS), and Pice formed a complex with $\mathrm{Cu}$ (II). The reaction presumably led to the formation of 'oxidized product(s)' of Pice, which also catalyzed the reduction of $\mathrm{Cu}(\mathrm{II})$. In addition, the biological activity of the reaction system was studied. We found that the Pice-Cu(II)-mediated reaction induced pBR322 DNA breakage. Such studies are significant not only in designing novel anti-tumor agents but also in developing more effective approaches to prevent and/or control cancer through dietary intervention.

\section{Materials and methods}

Materials. Supercoiled plasmid pBR322 DNA was purchased from Bio Basic Inc.(Markham Ontario, Canada). Bathocuproine was purchased from Acros Organics (Pittsburgh, PA, USA). The Plasmid Maxi Preparation kit was purchased from Omega Biotek Inc. (Doraville, GA, USA). All the other chemicals were of analytical grade. Pice was dissolved in dehydrated alcohol as a $1 \mathrm{mM}$ stock solution and stored at $-20^{\circ} \mathrm{C}$ in the dark; $\mathrm{CuSO}_{4}$ was dissolved in ultrapure water as a $1 \mathrm{mM}$ stock solution. Both Pice and $\mathrm{CuSO}_{4}$ were diluted with $0.01 \mathrm{M}$ phosphate-buffered saline (PBS) prior to use, and the diluted solution was used within $2 \mathrm{~h}$.

DNA-cleaving activity. DNA strand breakage was measured in terms of conversion of supercoiled pBR322 plasmid DNAs to open circular or linear forms by gel electrophoresis. The reaction mixture $(10 \mu \mathrm{l})$ contained $100 \mathrm{ng}$ pBR322 DNA, $200 \mu \mathrm{M}$ $\mathrm{CuSO}_{4}$ and $200 \mu \mathrm{M}$ Pice, equal molar antioxidants and metal ion chelating agents in PBS at $\mathrm{pH}$ 7.4. After being preincubated for $1 \mathrm{~h}$ at $37^{\circ} \mathrm{C}$, the reaction mixture was treated with $2 \mu 1$ loading buffer (6X), and then immediately loaded onto a $1.2 \%$ agarose gel containing $1 \mu \mathrm{g} / \mathrm{ml}$ gelview. Horizontal gel electrophoresis was performed in $1 \mathrm{X}$ TBE buffer $(\mathrm{pH} \mathrm{8.3)}$ ) and photographed with ultraviolet-visible (UV-visible) transillumination.

UV-visible spectra measurements. UV-visible spectra were measured with a TU-1901 dual beam UV-visible spectrophotometer (Beijing Purkinje General Instrument Co., Ltd., Beijing, China).

Time-related $U V$-visible spectra of Pice-Cu(II). A reaction mixture (2 ml) containing $50 \mu \mathrm{M}$ Pice in PBS (pH 7.4) was prepared and underwent spectral analysis. The spectral tracing was started by adding $1 \mathrm{ml}$ of $50 \mu \mathrm{M} \mathrm{CuSO}_{4}$. The spectra were recorded every 5 min after adding $\mathrm{CuSO}_{4}$ until the variation was invisible.

Stoichiometry of $\mathrm{Cu}(\mathrm{I})$ production. Varying amounts of Pice and $\mathrm{Cu}$ (II) were added to the reaction mixture $(2 \mathrm{ml})$ containing $0.01 \mathrm{M}$ PBS ( $\mathrm{pH} 7.4$ ) and $300 \mu \mathrm{M}$ bathocuproine, and the final reaction volume was maintained at $3 \mathrm{ml}$ by adding PBS. The bathocuproine- $\mathrm{Cu}(\mathrm{I})$ complex was determined by measuring the absorbance at $480 \mathrm{~nm}$ following incubation for $10 \mathrm{~min}$ at room temperature (33).

Formation of Pice-Cu(II) complex. Ethylenediaminetetraacetic acid (EDTA), a well-known chelating agent for metal ions, was used to detect the formation of the Pice- $\mathrm{Cu}$ (II) complex. The reaction mixture (final volume of $3 \mathrm{ml}$ ) contained $50 \mu \mathrm{M}$ Pice, EDTA and $\mathrm{Cu}(\mathrm{II})$ in PBS. The spectra of the reaction mixtures were measured when $\mathrm{Cu}(\mathrm{II})(50 \mu \mathrm{M})$ had reacted for $10 \mathrm{~min}$ before and after the addition of EDTA, respectively.

Interaction between Pice and pBR322 DNA. The interaction between Pice and pBR322 DNA was detected at $17^{\circ} \mathrm{C}$ and $37^{\circ} \mathrm{C}$, respectively. The PBS reaction mixtures $(3 \mathrm{ml})$ contained $50 \mu \mathrm{M}$ Pice and 100, 200 and $400 \mu \mathrm{l}$ pBR322 DNA (30 ng/ $\mu \mathrm{l}$ ), respectively. The spectra were measured after incubation for $1 \mathrm{~h}$ at $17^{\circ} \mathrm{C}$ and $37^{\circ} \mathrm{C}$, respectively.

The interaction between Pice and pBR322 DNA in the presence of $\mathrm{Cu}(\mathrm{II})$ was also detected at $37^{\circ} \mathrm{C}$. The PBS reaction mixtures $(3 \mathrm{ml})$ contained $50 \mu \mathrm{M}$ Pice, $\mathrm{Cu}(\mathrm{II})$, and 100 , 200 and $400 \mu \mathrm{l}$ DNA, respectively. The spectra were measured following incubation for $1 \mathrm{~h}$ at $37^{\circ} \mathrm{C}$.

Fluorescence measurements. Fluorescence spectra were recorded on an LS-55 fluorescence spectrophotometer (Perkin-Elmer) in a $1-\mathrm{cm}$ quartz cuvette using an excitation wavelength of $280 \mathrm{~nm}$ and an emission wavelength of 300-500 $\mathrm{nm}$. The slit widths for excitation and emission were set at $10 \mathrm{~nm}$. The PBS reaction mixture (final volume of $3 \mathrm{ml}$ ) consisted of $50 \mu \mathrm{M}$ Pice, 0 or $400 \mu \mathrm{l}$ pBR322 DNA (30 ng/ $\mu \mathrm{l}$ ) and $50 \mu \mathrm{M}$ Pice. The spectra were measured following incubation for $1 \mathrm{~h}$ at $37^{\circ} \mathrm{C}$.

Fourier transform infrared (FTIR) measurements. The infrared spectra were recorded as KBr pellets on an FTS 3000 FTIR spectrometer, within a wavelength range of $650-4000 \mathrm{~cm}^{-1}$, and captured at a spectral range by accumulating 32 scans with a resolution of $4 \mathrm{~cm}^{-1}$. It should be noted that Pice is easily oxidized during the FTIR spectra measurement, which causes difficulty when measuring the spectra directly, whereas Res is stable and shares a similar structure with Pice. Therefore, Res was used as a control to determine the structure of the product(s) of Pice- $\mathrm{Cu}(\mathrm{II})$.

\section{Results}

Strand breakage of plasmid pBR322 DNA induced by Pice in the presence of $C u(I I)$. The cleaved supercoiled pBR322 DNA and the open circular and linear DNA were used to assess DNA strand breakage (33). We found that at a concentration 


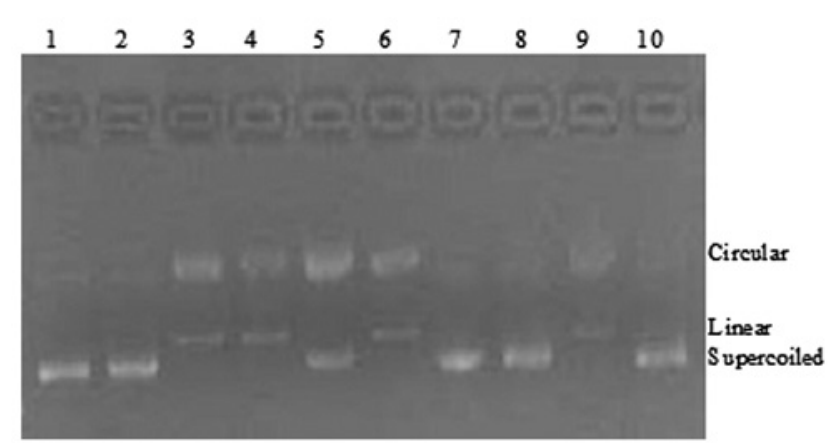

Figure 1. Mechanism of Pice-Cu(II)-mediated degradation of pBR322 DNA: lane 1, DNA; lane 2, DNA+Pice; lane 3, DNA+Pice+Cu(II); lane 4, $\mathrm{DNA}+\mathrm{Pice}+\mathrm{Cu}(\mathrm{II})+\mathrm{Vc}$; lane $5, \mathrm{DNA}+\mathrm{Pice}+\mathrm{Cu}(\mathrm{II})+\mathrm{GSH}$ (the type of reduction); lane 6, DNA+Pice+Cu(II)+Bath; lane 7, DNA+Pice+Cu(II)+mannitol lane 8, DNA+Pice+Cu(II)+EDTA; lane 9, DNA+Pice+EDTA+Cu(II); lane 10, DNA $+\mathrm{Cu}(\mathrm{II})$. Pice, piceatannol; Bath, bathocuproine; GSH, glutathion.

of $200 \mu \mathrm{M}$, neither Pice nor $\mathrm{Cu}(\mathrm{II})$ alone showed the ability to damage DNA (Fig. 1, lanes 2 and 10). However, $\mathrm{Cu}$ (II) and Pice worked cooperatively to break the supercoiled DNA (Fig. 1, lane 3).

To clarify the roles of oxygen-derived active species in the DNA strand breakage induced by Pice in the presence of $\mathrm{Cu}(\mathrm{II})$, the free radical scavengers and the $\mathrm{Cu}(\mathrm{I}) / \mathrm{Cu}(\mathrm{II})$ chelator were used to prevent DNA strand breakage. Antiscorbic acid (antioxidant), glutathion (GSH, ROS scavenger), mannitol (HO` scavenger), EDTA [the specific $\mathrm{Cu}(\mathrm{II})$ chelator] and bathocuproine (the specific $\mathrm{Cu}(\mathrm{I})$ chelator) were all provided to protect pBR322 plasmid DNA against strand breakage induced by Pice in the presence of $\mathrm{Cu}$ (II). It was found that antiscorbic acid did not prevent DNA strand breakage (Fig. 1, lane 4), whereas GSH and mannitol completely prevented DNA strand breakage (Fig. 1, lanes 5 and 7), indicating that ROS, particularly $\mathrm{HO}^{\circ}$, is important in inducing DNA breakage. Bathocuproine did not effectively protect DNA from breakage (Fig. 1, lane 6), whereas EDTA was able to protect DNA from breakage (Fig. 1, lane 8), although the protection was depressed if EDTA was added after Pice-Cu(II) had reacted with DNA for 15 min (Fig. 1, lane 9). These results suggest that both $\mathrm{ROS}(\mathrm{HO} \cdot)$ and $\mathrm{Cu}(\mathrm{II})$ are critical to DNA damage.

$U V$-visible spectral changes of Pice in the presence of $\mathrm{Cu}(I I)$. To clarify the mechanism of DNA damage induced by the Pice-Cu(II) system, the UV-visible absorption changes of Pice in the presence of $\mathrm{Cu}(\mathrm{II})$ in PBS buffer ( $\mathrm{pH}$ 7.4) under aerobic conditions were measured (Fig. 2). The peaks of Pice absorption were at 218 and $323 \mathrm{~nm}$ (Fig. 2). When $\mathrm{Cu}$ (II) was added to Pice, the absorbance at $323 \mathrm{~nm}$ disappeared rapidly, accompanied by a red shift at $332 \mathrm{~nm}$, which provided evidence of the formation of the chelate complex Pice- $\mathrm{Cu}(\mathrm{II})$. The absorbance at $332 \mathrm{~nm}$ decreased with increasing time. A blue shift was also found from 218 to $208 \mathrm{~nm}$ with the increasing absorbance, which signaled the formation of new product(s). A new weak peak appeared near $459 \mathrm{~nm}$, due to the formation of the ortho-semiquinone anion. In addition, the ortho-semiquinone radical anion was more easily oxidized to form the final product ortho-quinone (35).

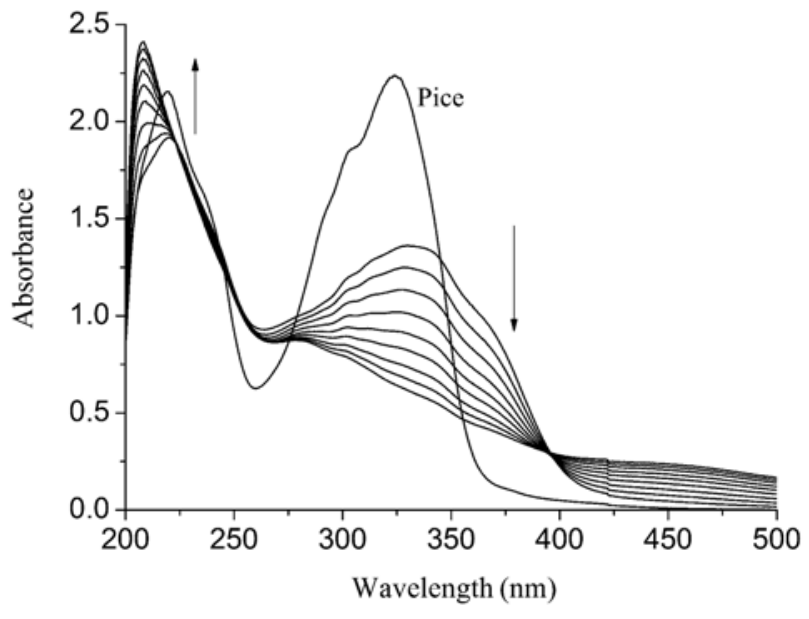

Figure 2. Time-related absorption spectra of Pice-Cu(II). Pice, piceatannol.

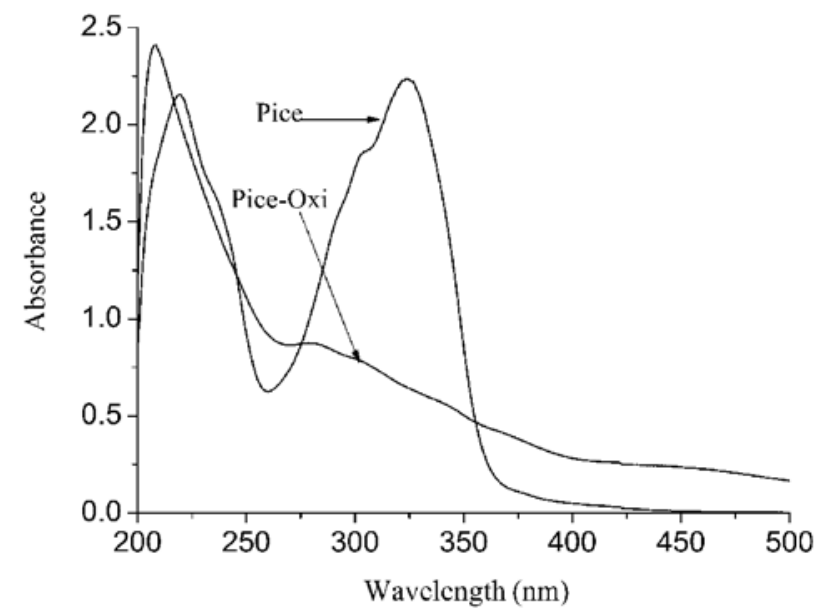

Figure 3. UV absorption spectra of Pice and its oxidative products. Pice, piceatannol.

Two isosbestic points at 248 and $395 \mathrm{~nm}$ and the isosbestic point at $395 \mathrm{~nm}$ suggested a direct transition from one form [Pice-Cu(II) complex] to another (ortho-semiquinone anion).

To further understand the mechanism underlying the reaction of the Pice-Cu(II) system, the UV-visible spectrum of the oxidative product(s) of Pice was measured (Fig. 3). In Fig. 3, the spectrum of the oxidative product(s) is identical to that of the reaction product(s) of the Pice-Cu(II) system, indicating that the oxidative product(s) of Pice is one of the reaction product(s) of the Pice-Cu(II) system. Thus, Pice was oxidized and the reducing agent would be $\mathrm{Cu}$ (II) in this reaction, and the reaction mechanism was similar to that of other polyphenolic compounds (2).

If the reducing agent was $\mathrm{Cu}(\mathrm{II}), \mathrm{Cu}(\mathrm{I})$ would be formed. To detect $\mathrm{Cu}(\mathrm{I})$ in the reaction system, bathocuproine, a selectively trapping agent of $\mathrm{Cu}(\mathrm{I})$ was used. The absorbance at $480 \mathrm{~nm}$ provided evidence of the formation of the bathocuproine- $\mathrm{Cu}(\mathrm{I})$ complex (33). The result of the production of $\mathrm{Cu}(\mathrm{I})$ by stoichiometry is shown in Fig. 4. The absorbance at $480 \mathrm{~nm}$ was shown to vary with the molar ratio of Pice to $\mathrm{Cu}(\mathrm{II})$, indicating the existence of $\mathrm{Cu}(\mathrm{I})$ in the $\mathrm{Pice}-\mathrm{Cu}(\mathrm{II})$ reaction system. No clear maximum was found where the absorption 


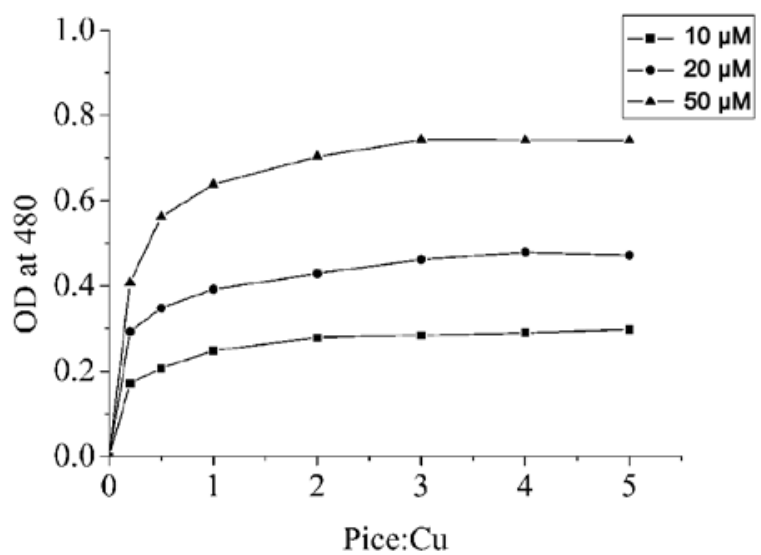

Figure 4. Differences in absorbance at $480 \mathrm{~nm}$ of samples with and without added $\mathrm{Cu}(\mathrm{II})$ is plotted vs. equivalents of $\mathrm{Cu}$ (II) per molar equivalent of Pice (concentration of bathocuproine used was $300 \mathrm{mM}$ in all cases). Pice, piceatannol. OD, optical density.

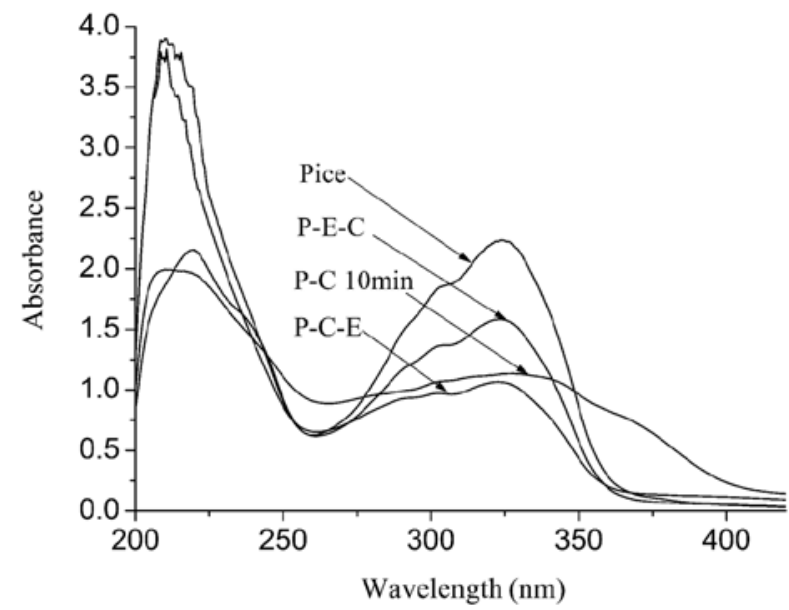

Figure 5. Confirmation of the complex compound between $\mathrm{Cu}(\mathrm{II})$ and Pice. Pice/P, piceatannol; E, EDTA; C, Cu(II).

reached a plateau, suggesting that copper ions may be recycled in this reaction (Fig. 4).

As $\mathrm{Cu}(\mathrm{II})$ was reduced to $\mathrm{Cu}(\mathrm{I})$ by Pice, it is essential to clarify whether the Pice-Cu(II) complex was formed. A well-known chelating agent for metal ions, EDTA, was used to confirm the formation of the Pice-Cu(II) complex (Fig. 5). When $\mathrm{Cu}$ (II) was added to Pice, the peak at $323 \mathrm{~nm}$ disappeared and the red-shifted peak appeared at $332 \mathrm{~nm}$. Upon addition of EDTA after $10 \mathrm{~min}$, the red-shifted band $(332 \mathrm{~nm})$ returned to its initial position $(323 \mathrm{~nm})$ with a decrease in absorbance. If EDTA was added to Pice before $\mathrm{Cu}(\mathrm{II})$, the spectrum of Pice changed more weakly than it did when EDTA was added after $\mathrm{Cu}(\mathrm{II})$, and there was no peak shift. The above phenomena therefore indicate that Pice chelates with $\mathrm{Cu}(\mathrm{II})$ as a bidentate ligand, thus facilitating intramolecular electron transfer to form the stable ortho-semiquinone anion (Fig. 2).

Mechanism of Pice-DNA and Pice-DNA-Cu(II). The absorption band of electrons is commonly used to study the interactions between micromolecules and DNA. In general,

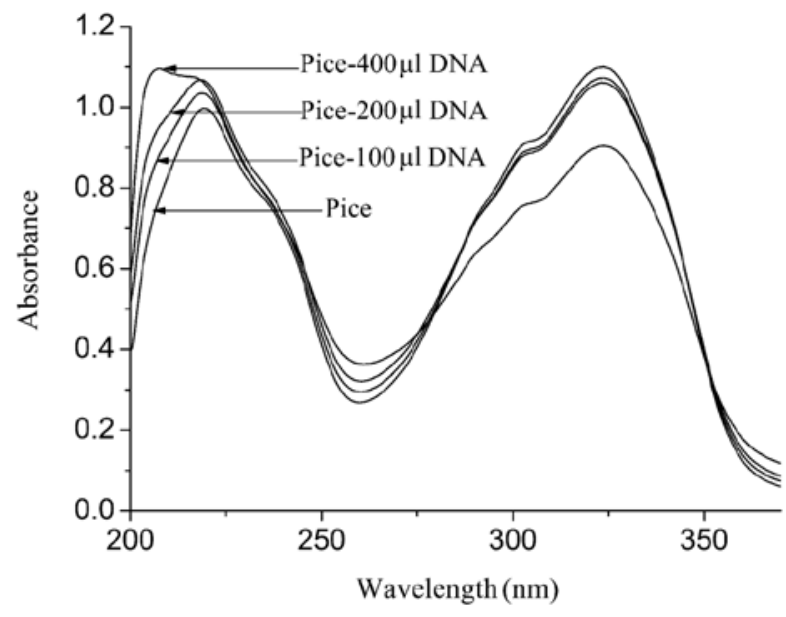

Figure 6. Spectra of Pice with different DNA levels at $17^{\circ} \mathrm{C}$. Pice, piceatannol.

micromolecules possess electron absorption in the UV-visible region, and their electron atmosphere varies in the presence of DNA, which causes the variation of ligand circumstance. These phenomena may be demonstrated using the electron absorption spectrum.

When intercalation occurs between DNA and micromolecules, the absorption intensity of micromolecules degrades, and the absorption peak shows a red shift effect. $\pi$ electron accumulation may occur between the intercalating ligand and base pairs of DNA, which may cause the conjugation between the $\pi^{*}$ vacant orbital of micromolecules and the $\pi$ electron orbital of DNA base pairs. The decrease in the energy level induces $\pi \rightarrow \pi^{*}$ transition energy decrease and generates the red shift effect, and the degree of the red shift reflects the ability of intercalation.

The bathochromic effect occurs following the micromolecule-DNA reaction, and the extent of the bathochromic shift increases with the increasing concentration of DNA, which indicates that the molecular aggregation and hydrogen bond damage cause interactions between micromolecules (36). If the electrostatic interaction and groove binding occur, the weak red shift and hypochromic effect may appear.

Fig. 6 shows the spectra of Pice with different DNA levels at $17^{\circ} \mathrm{C}$. Following the addition of pBR322 DNA, the absorbance of Pice at $323 \mathrm{~nm}$ decreased with the increasing DNA levels following the weak red shift $(3 \mathrm{~nm})$. These changes indicated that the interaction between Pice and DNA was groove binding. The absorption at $218 \mathrm{~nm}$ increased, and when the DNA level increased to $400 \mu$ l, the blue shift occurred from 218 to $205 \mathrm{~nm}$, suggesting that the katogene in hydrogen bond and molecular aggregation of Pice also existed besides the intercalation (36).

The spectra of Pice with different DNA levels at $37^{\circ} \mathrm{C}$ are shown in Fig. 7. In contrast to the situation at $17^{\circ} \mathrm{C}$, the hypochromic effect and the red shift were evident, indicating that intercalation also occurred between Pice and DNA. Similar to the situation at $218 \mathrm{~nm}$, the hyperchromic effect was further elevated and the absorption peak moved to $208 \mathrm{~nm}$ instead of $205 \mathrm{~nm}$ with an increase in DNA, indicating that oxidization also occurred in the reaction system. All of these factors 


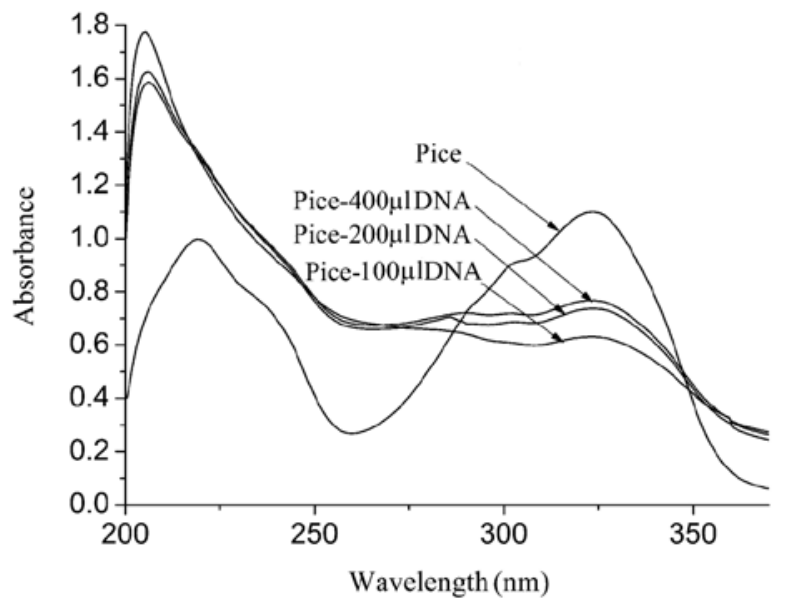

Figure 7. Spectra of Pice with different DNA levels at $37^{\circ} \mathrm{C}$. Pice, piceatannol.

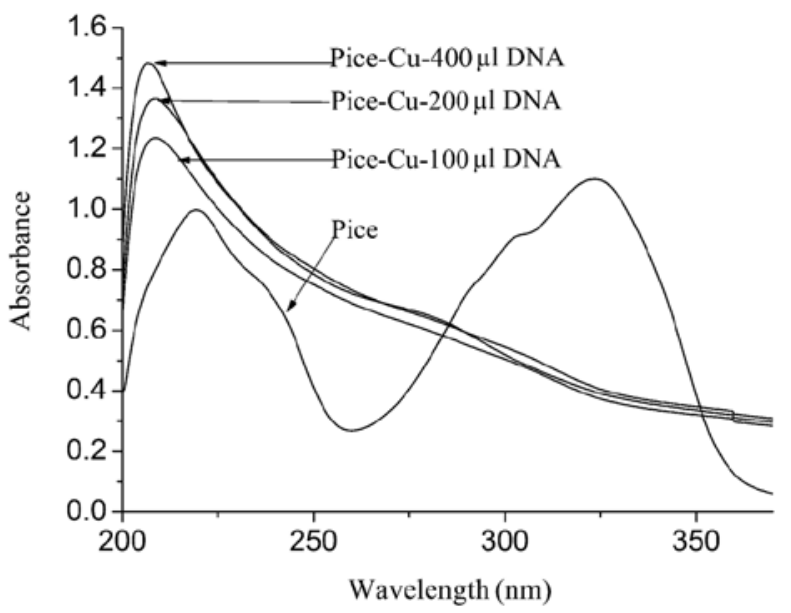

Figure 8. Spectra of Pice-Cu(II) with different DNA levels at $37^{\circ} \mathrm{C}$. Pice, piceatannol.

suggest that the degree of the interaction between Pice and DNA positively correlated with the temperature.

To further elucidate the mechanism of DNA breakage, the spectra of Pice with different DNA levels at $37^{\circ} \mathrm{C}$ in the presence of $\mathrm{Cu}(\mathrm{II})$ were determined (Fig. 8). The absorption peak at $323 \mathrm{~nm}$ disappeared when $\mathrm{Cu}(\mathrm{II})$ was present in the reaction system, the blue shift occurred at $218 \mathrm{~nm}$, and the peak moved from 218 to $208 \mathrm{~nm}$ accompanied by the increase in absorbance. These results combined with those obtained in the former sections indicate that Pice was oxidized completely in this reaction system. From these results, we hypothesized that the intermediate product mainly caused the damage to DNA.

Fluorescence spectra of Pice, Pice-DNA and Pice-DNA-Cu(II). DNA possessed no endogenous flourescence, although it affected the fluorescence character of the micromolecule through the interactions. In general, the fluorescence intensity was enhanced, and the degree of the enhancement was correlated with the degree of binding. Notably, the rigidity of the micromolecule was enhanced, whereas the micromolecule

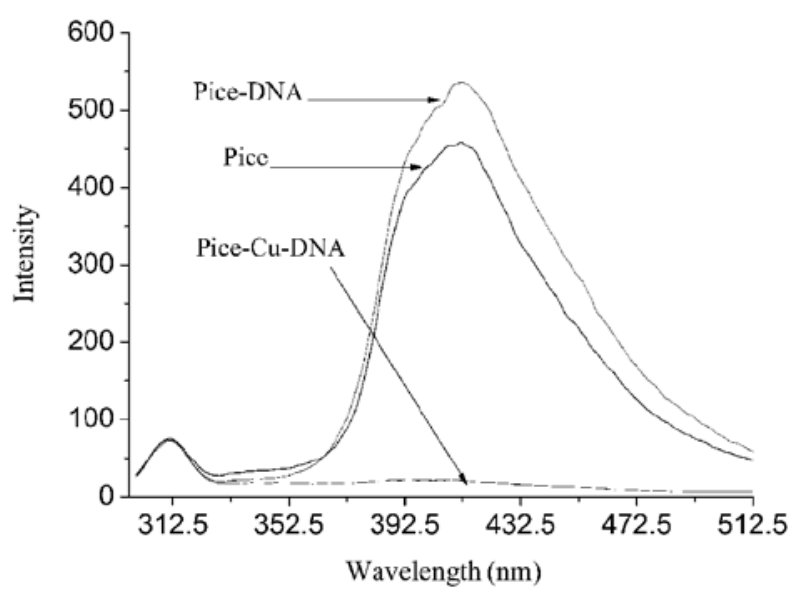

Figure 9. Fluorescence spectra of Pice, Pice-DNA, and Pice-Cu(II)-DNA at $37^{\circ} \mathrm{C}$. Pice, piceatannol.

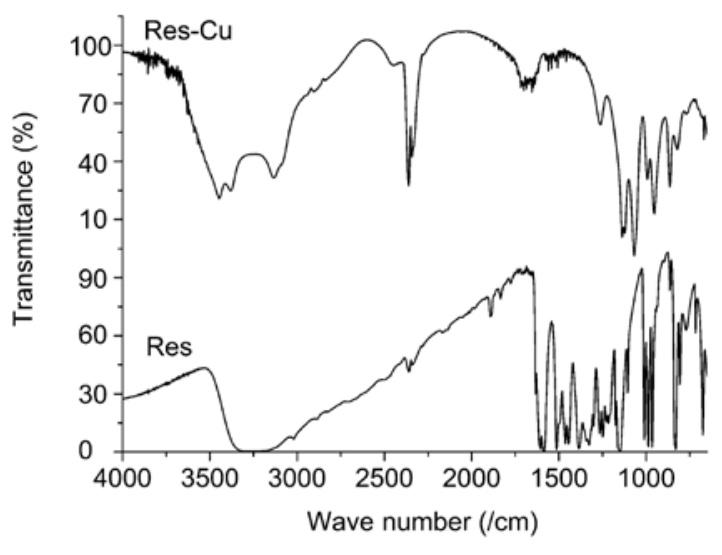

Figure 10. Fourier transform infrared (FTIR) spectra of Res and the reaction product of Res-Cu(II). Res, Resveratrol.

entered the hydrophobic environment from the hydrophilic environment, which also increased the fluorescence intensity.

The fluorescence spectra of Pice, Pice-DNA and Pice- $\mathrm{Cu}(\mathrm{II})-\mathrm{DNA}$ at $37^{\circ} \mathrm{C}$ were measured. As shown in Fig. 9, with the addition of DNA, the fluorescence intensity of Pice increased, mainly due to the hydrophobic protection of DNA. Simultaneously, the architecture of the DNA was damaged.

FTIR spectra. To determine the structure of Pice, the FTIR spectra of Res, Pice and the reaction product of Res-Cu(II) were measured (Figs. 10 and 11). We found that the medium intensity band emerged in the range $3000-3500 \mathrm{~cm}^{-1}$, which was attributed to the phenolic hydroxyl group $[v(\mathrm{OH})]$ of Res; $1630 \mathrm{~cm}^{-1}$, which was attributed to the stretching vibration of $-\mathrm{C}=\mathrm{C}$ - outside the aromatic ring; 675 and $806 \mathrm{~cm}^{-1}$, which was attributed to the out-of-plane bending vibration of $=\mathrm{CH}$ in the aromatic ring. The bands of $990-1300 \mathrm{~cm}^{-1}$ were attributed to the in-plane bending vibration of $=\mathrm{C}-\mathrm{H}$ in the aromatic ring, and the several sharp bands of 1606, 1585, 1514, 1465 and $1384 \mathrm{~cm}^{-1}$ were attributed to the in-plane stretching vibration of $-\mathrm{C}=\mathrm{C}$ - in the aromatic ring. In the produce(s) spectrum of Res, 


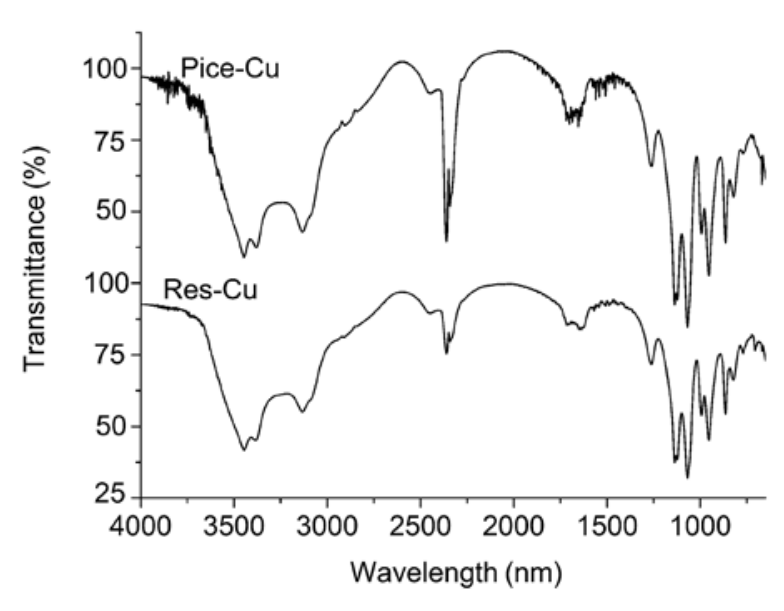

Figure 11. Fourier transform infrared (FTIR) spectra of the reaction product of $\mathrm{Res}-\mathrm{Cu}(\mathrm{II})$ and $\mathrm{Pice}-\mathrm{Cu}(\mathrm{II})$.

the out-of-plane bending vibration of $=\mathrm{CH}$ and the in-plane stretching vibration of $-\mathrm{C}=\mathrm{C}$ - in the aromatic ring disappeared, and the new band at $1650-1680 \mathrm{~cm}^{-1}$ appeared, which was attributed to the stretching vibration of quinonyl. These results indicate that the aromatic ring in Res was destroyed when $\mathrm{Res}$ reacted with $\mathrm{Cu}(\mathrm{II})$. The product was semiquinone, which was the oxidative product of Res. It was also found that the bands of the in-plane bending vibration of $=\mathrm{C}-\mathrm{H}$ in the aromatic ring varied, which further confirmed the conclusion.

From the FTIR spectra of the reaction product of $\mathrm{Res}-\mathrm{Cu}(\mathrm{II})$ and Pice-Cu(II) in Fig. 11, two products were shown to have an almost identical spectrum structure, which suggested that the reaction mechanism of Res-Cu(II) and Pice-Cu(II) was identical. When Res was taken into account, oxidized forms of Pice were produced in the presence of $\mathrm{Cu}$ (II).

\section{Discussion}

In this study, the mechanism of oxidative DNA damage induced by Pice in the presence of $\mathrm{Cu}(\mathrm{II})$ was investigated in detail. Our results show that Pice is effective as an antioxidant, and it may become pro-oxidant in the presence of $\mathrm{Cu}(\mathrm{II})$ to induce DNA damage.

The Res-Cu(II)-induced oxidative DNA damage was previously studied $(5,33,35)$. Similarly, although Pice is widely believed to be an antioxidant, our results support its pro-oxidant properties. According to the structure-activity relationship of the compounds in Res and its analogs, the compounds bearing ortho-dihydroxyl groups, followed by compounds bearing 4-hydroxyl groups, are the most active in inducing plasmid pBR322 DNA strand breakage and calf thymus DNA damage in the presence of $\mathrm{Cu}(\mathrm{II})$ (35). Obviously, the high activity of Pice is due to its ortho-dihydroxyl group which is capable of chelating with $\mathrm{Cu}$ (II) to form Pice- $\mathrm{Cu}$ (II) complexes. The Pice- $\mathrm{Cu}$ (II) complex is able to undergo intramolecular electron transfer to form semiquinone radical anion and $\mathrm{Cu}(\mathrm{I})$.

Possible mechanisms of DNA damage induced by Pice in the presence of $\mathrm{Cu}(\mathrm{II})$ are shown as follows:

$$
\begin{aligned}
& \text { Pice }(\mathrm{OH})_{4} \rightleftarrows \operatorname{Pice}(\mathrm{OH})_{2} \mathrm{O}_{2}^{-}+2 \mathrm{H}^{+} \\
& \text {Pice }(\mathrm{OH})_{2} \mathrm{O}_{2}^{-}+\mathrm{Cu}(\mathrm{II}) \rightarrow \operatorname{Pice}(\mathrm{OH})_{2} \mathrm{O}_{2}^{--}+\mathrm{Cu}(\mathrm{I}) \\
& \mathrm{Cu}(\mathrm{I})+\mathrm{O}_{2} \rightarrow \mathrm{Cu}(\mathrm{II})+\mathrm{O}_{2}^{--} \\
& 2 \mathrm{O}_{2}^{--}+2 \mathrm{H}^{+} \rightarrow \mathrm{H}_{2} \mathrm{O}_{2}+\mathrm{O}_{2} \\
& \mathrm{Cu}(\mathrm{I})+\mathrm{H}_{2} \mathrm{O}_{2} \rightarrow \mathrm{Cu}(\mathrm{II})+\mathrm{OH}+\mathrm{OH}^{-} \quad \text { (Fenton reaction) } \\
& \mathrm{O}_{2}^{--}+\mathrm{H}_{2} \mathrm{O}_{2} \rightarrow \mathrm{OH}+\mathrm{OH}^{-}+\mathrm{O}_{2} \quad \text { (Haber Weiss reaction) } \\
& \mathrm{Pice}(\mathrm{OH})_{2} \mathrm{O}_{2}^{\cdot}+\mathrm{Cu}(\mathrm{I})+\mathrm{O}_{2} \rightarrow \mathrm{Cu}(\mathrm{II})+\text { ortho-quinone }
\end{aligned}
$$

The initial electron transfer oxidation of Pice induced by $\mathrm{Cu}(\mathrm{II})$ generates the corresponding semiquinone radical anion. Reacting with $\mathrm{O}_{2}$, the radical undergoes a second electron transfer to form ortho-quinone (and para-quinone) and $\mathrm{O}_{2}{ }^{-}$. At neutral $\mathrm{pH}, \mathrm{O}_{2}{ }^{-}$protonates and forms $\mathrm{H}_{2} \mathrm{O}_{2} \cdot \mathrm{H}_{2} \mathrm{O}_{2}$ may also be formed by dismutation of $\mathrm{O}_{2}{ }^{-}$. Thus, $\mathrm{H}_{2} \mathrm{O}_{2}$ can immediately participate in both Haber Weiss and Fenton-type ${ }^{\circ} \mathrm{OH}$ formation and DNA cleavage reaction. In addition, $\mathrm{Cu}$ (II) can be reduced to $\mathrm{Cu}$ (I) by Pice, and it is the reoxidation of $\mathrm{Cu}$ (I) to $\mathrm{Cu}$ (II) that gives rise to ${ }^{\circ} \mathrm{OH}$, the main radical that induces DNA damage. Thus, presumably the mechanism of DNA cleavage induced by Pice-Cu(II) is a complex one involving the Haber Weiss and Fenton reactions and reduction of $\mathrm{Cu}$ (II). In addition, orthoquinones are reportedly involved in DNA damage by forming covalent adducts with DNA $(4,37,38)$. In brief, the formation of the hydroxyl radical and the $\mathrm{Cu}(\mathrm{II}) / \mathrm{Cu}(\mathrm{I})$ redox cycle play a key role in inducing DNA damage.

Among the oxygen radicals, the hydroxyl radical is the most electrophilic, with a high reactivity, and therefore possesses a small diffusion radius. Thus, to cleave DNA, the hydroxyl radical should be produced in the vicinity of DNA (7). Copper is one of the most redox-active metal ions present in cells and is closely associated with chromatin. Copper concentration in tissues increases in various malignancies (8). Copper ions from chromatin may be mobilized by Res and other polyphenols, resulting in DNA breakage in cells, the hallmark of cell apoptosis (39). Since Res has been detected in tissues such as the kidney and liver, it is reasonable to assume that Res is transported across cell membranes due to its lipophilic nature (40). Pice, as the metabolite of Res, is transported across cell membranes, thus becoming potentially available for cell uptake and intracellular signaling. In addition, the polyphenol curcumin-mediated apoptosis of HL60 cells has been shown to be closely related to the increase in concentration of reactive oxygen species, possibly through the reduction of transition metal ions in cells (41). Therefore, the mechanism of DNA breakage induced by Pice-Cu(II) may be an important pathway through which cancer cells are killed while normal cells survive.

The antineoplastic activity of Pice also involves the intercalation of drugs into DNA, which eventually leads to DNA damage (42). Our results suggest that the intercalation of Pice into DNA occurs, which may be another mechanism of its anticancer activity. The mechanism of DNA damage induced by Pice-Cu(II) is similar to that of known anticancer drugs, such as camptothecin, etoposide and $\gamma$-radiation (9). Therefore, 
Pice-Cu(II)-mediated DNA cleavage is physiologically feasible and may have biological significance.

\section{Acknowledgements}

This study was financially supported by the National Natural Science Foundation of China (grant no. 81000670) and the Chongqing Scientific and Technological Key Task Program (grant no. 2011AC5025). We would like to thank Miss Xie-Wan Chen and Ms. Xiao-Qing Zhan (Medical English Department, Third Military Medical University, China) for the critical reading of the manuscript and for her valuable advice.

\section{References}

1. Galati G and O'Brien PJ: Potential toxicity of flavonoids and other dietary phenolics: significance for their chemopreventive and anticancer properties. Free Radic Biol Med 37: 287-303, 2004.

2. Bhat SH, Azmi AS and Hadi SM: Prooxidant DNA breakage induced by caffeic acid in human peripheral lymphocytes: involvement of endogenous copper and a putative mechanism for anticancer properties. Toxicol Appl Pharmacol 218: 249-255, 2007.

3. Ahmad A, Syed FA, Singh S and Hadi SM: Prooxidant activity of resveratrol in the presence of copper ions: mutagenicity in plasmid DNA. Toxicol Lett 15: 1-12, 2005.

4. Jung YJ and Surh YJ: Oxidative DNA damage and cytotoxicity induced by copper-stimulated redox cycling of salsolinol, a neurotoxic tetrahydroisoquinoline alkaloid. Free Radic Biol Med 30: 1407-1417, 2001.

5. Fukuhara K, Nagakawa M, Nakanishi I, Ohkubo K, Imai K, Urano S, Fukuzumi S, Ozawa T, Ikota N, Mochizuki M, Miyata N and Okuda H: Structural basis for DNA-cleaving activity of resveratrol in the presence of $\mathrm{Cu}(\mathrm{II})$. Bioorg Med Chem 14: $1437-1443,2006$.

6. Fukuhara $\mathrm{K}$ and Miyata N: Resveratrol as a new type of DNA-cleaving agent. Bioorg Med Chem Lett 8: 3187-3192, 1998.

7. Azmi AS, Bhat SH, Hanif S and Hadi SM: Plant polyphenols mobilize endogenous copper in human peripheral lymphocytes leading to oxidative DNA breakage: A putative mechanism for anticancer properties. FEBS Letters 580: 533-538, 2006.

8. Ebara M, Fukuda H, Hatano R, Saisho H, Nagato Y, Suzuki K, Nakajima K, Yukawa M, Kondo F, Nakayama A and Sakurai H: Relationship between copper, zinc and metallothionein in hepatocellular carcinoma and its surrounding liver parenchyma. J Hepatol 33: 415-422, 2000.

9. Hadi SM, Asad SF, Singh S and Ahmad A: Putative mechanism for anticancer and apoptosis-inducing properties of plant-derived polyphenolic compounds. IUBMB Life 50: 167-171, 2000.

10. Dipak KD and Nilanjana M: Resveratrol in cardioprotection: a therapeutic promise of alternative medicine. Mol Interv 6: 36-47, 2006.

11. Meherzia M, Ferid L, Salem E, Mohamed A and Ezzedine A: Strong cardioprotective effect of resveratrol, a red wine polyphenol, on isolated rat hearts after ischemia/reperfusion injury. Arch Biochem Biophys 457: 1-6, 2007.

12. Shyamal KG and Dipak KD: Resveratrol and chemoprevention. Cancer Letters 284: 1-6, 2009.

13. Athar M, Back JH, Tang XW, Kim KH, Kopelovich L, Bickers DR and Kim AL: Resveratrol: A review of preclinical studies for human cancer prevention. Toxicol Appl Pharmacol 224: 274-283, 2007.

14. Asensi M, Medina I, Ortega A, Corretera J, Carmen-Bano M, Obrador E and Estrela MJ: Inhibition of cancer growth by resveratrol is related to its low bioavailability. Free Radic Biol Med 33: 387-398, 2002.

15. Marier JF, Vachon P, Gritsas A, Zhang J, Moreau JP and Ducharme MP: Metabolism and disposition of resveratrol in rats: extent of absorption, glucuronidation, and enterohepatic recirculation evidenced by a linked-rat model. J Pharmacol Exp Ther 302: 369-373, 2002
16. Yu C, Shin YG, Kosmeder JW, Pezzuto JM and Van Breemen RB: Liquid chromatography/tandem mass spectrometric determination of inhibition of human cytochrome P450 isozymes by resveratrol and resveratrol-3-sulfate. Rapid Commun Mass Spectrom 17: 307-313, 2003.

17. Ferrigni NR, McLaughlin JL, Powell RG and Smith CR: Use of potato disc and brine shrimp bioassays to detect activity and isolate piceatannol as the antileukemic principle from the seeds of Euphorbia lagascae. J Nat Prod 47: 347-352, 1984.

18. Cantos E, Espin JC, Fernandez MJ, Oliva J and Tomas-Barberan FA: Postharvest UV-C-irradiated grapes as a potential source for producing stilbene-enriched red wines. J Agric Food Chem 51: 1208-1214, 2003.

19. Ku KL, Chang PS, Cheng YC and Lien CY: Production of stilbenoids from the callus of Arachis hypogaea: a novel source of the anticancer compound piceatannol. J Agric Food Chem 53: 3877-3881, 2005.

20. Matsuda H, Tomohiro N, Hiraba K, Harima S, Ko S, Matsuo K, Yoshikawa $\mathrm{M}$ and Kubo M: Study on anti-Oketsu activity of rhubarb II. Anti-allergic effects of stilbene components from Rhei undulati Rhizoma (dried rhizome of Rheum undulatum cultivated in Korea). Biol Pharm Bull 24: 264-267, 2001.

21. Rimando AM, Kalt W, Magee JB, Dewey J and Ballington JR: Resveratrol, pterostilbene, and piceatannol in vaccinium berries. J Agric Food Chem 52: 4713-4719, 2004.

22. Kim YH, Kwon HS, Kim DH, Cho HJ, Lee HS, Jun JG, Park JHY and Kim JK: Piceatannol, a stilbene present in grapes, attenuates dextran sulfate sodium-induced colitis. Int Immunopharmacol 8: $1695-1702,2008$

23. Jin CY, Moonb DO, Lee KJ, Kim MO, Lee JD, Choi YH, Park YM and Kimb GY: Piceatannol attenuates lipopolysaccharideinduced NF- $\kappa \mathrm{B}$ activation and NF- $\mathrm{NB}$-related proinflammatory mediators in BV2 microglia. Pharmacol Res 54: 461-467, 2006.

24. Kuo PL and Hsu YL: The grape and wine constituent piceatannol inhibits proliferation of human bladder cancer cells via blocking cell cycle progression and inducing Fas/membrane bound Fas ligand-mediated apoptotic pathway. Mol Nutr Food Res 52: 408-418, 2008.

25. Kim YH, Park C, Lee JO, Kim GY, Lee WH, Choi YH and Ryu CH: Induction of apoptosis by piceatannol in human leukemic U937 cells through down-regulation of Bcl-2 and activation of caspases. Oncol Rep 19: 961-967, 2008.

26. Potter GA, Patterson LH, Wanogho E, Perry PJ, Butler PC, Ijaz T, Ruparelia KC, Lamb JH, Farmer PB, Stanley LA and Burke MD: The cancer preventative agent resveratrol is converted to the anticancer agent piceatannol by the cytochrome P450 enzyme CYP1B1. Br J Cancer 86: 774-778, 2002.

27. Piver B, Fer M, Vitrac X, Merillon JM, Dreano Y, Berthou F and Lucas D: Involvement of cytochrome P450 1A2 in the biotransformation of trans-resveratrol in human liver microsomes. Biochem Pharmacol 68: 773-782, 2004.

28. Ovesná Z, Kozics K, Bader Y, Saiko P, Handler N, Erker T and Szekeres T: Antioxidant activity of resveratrol, piceatannol and $3,3^{\prime}, 4,4$ ',5,5'-hexahydroxy-trans-stilbene in three leukemia cell lines. Oncol Rep 16: 617-624, 2006.

29. Viola G, Acqua FD, Gabellini N, Moro S, Vedaldi D and Ihmels H: Indolo[2,3-b]-quinolizinium bromide: an efficient intercalator with DNA-photodamaging properties. Chembiochem 3: 550-558, 2002.

30. Cholody WM, Kosakowska-Cholody T, Hollingshead MG, Hariprakasha HK and Michejda CJ: A new synthetic agent with potent but selective cytotoxic activity against cancer. J Med Chem 48: 4474-4481, 2005.

31. Hotzel C, Marotto A and Pindur U: New propylamine oligopyrrole carboxamides linked to a heterocyclic or anthraquinone system: synthesis, DNA binding, topoisomerase I inhibition and cytotoxicity. Eur J Med Chem, 38: 189-197, 2003.

32. Rittich B, Spanová A, Falk M, Beneš MJ and Hrubý M: Cleavage of double stranded plasmid DNA by lanthanide complexes. J Chromatogr B 800: 169-173, 2004.

33. Ahmad A, Asad SF, Singh S and Hadi SM: DNA breakage by resveratrol and $\mathrm{Cu}(\mathrm{II})$ : reaction mechanism and bacteriophage inactivation. Cancer Lett 154: 29-37, 2000.

34. Selvakumar B, Rajendiran V,Uma Maheswari P, Stoeckli-Evans H and Palaniandavar M: Structures, spectra, and DNA-binding properties of mixed ligand copper(II) complexes of iminodiacetic acid: The novel role of diimine co-ligands on DNA conformation and hydrolytic and oxidative double strand DNA cleavage. J Inorg Biochem 100: 316-330, 2006. 
35. Zheng LF, Wei QY, Cai YJ, Fang JG, Zhou B, Yang L and Liu ZL: DNA damage induced by resveratrol and its synthetic analogues in the presence of $\mathrm{Cu}$ (II) ions: mechanism and structure-activity relationship. Free Radic Biol Med 41: 1807-1816, 2006.

36. Tu C, Wu XF, Liu Q, Wang XY, Xu Q and Guo ZJ: Crystal structure, DNA-binding ability and cytotoxic activity of platinum(II)2,2'-dipyridylamine complexes. Inorg Chim Acta 357: 95-102, 2004

37. Samuni AM, Chuang EY, Krishna MC, Stein W, DeGraff W, Russo A and Mitchell JB: Semiquinone radical intermediate in catecholic estrogen-mediated cytotoxic and mutagenesis: chemoprevention strategies with antioxidants. Proc Natl Acad Sci USA 100: 5390-5395, 2003.

38. Haque ME, Asanuma M, Higashi Y, Miyazaki I, Tanaka KI and Ogawa N: Apoptosis-inducing neurotoxicity of dopamine and its metabolites via reactive quinone generation in neuroblastoma cells. Biochim Biophys Acta 1619: 39-52, 2003.
39. Azmi AS, Bhat SH and Hadi SM: Resveratrol-Cu(II) induced DNA breakage in human peripheral lymphocytes: Implications for anticancer properties. FEBS Lett 579: 3131-3135, 2005.

40. Paola S and Riccardo G: Resveratrol as an anticancer nutrient: molecular basis, open questions and promises. J Nutr Biochem 16: 449-466, 2005.

41. Yoshino M, Haneda M, Naruse M, Htay HH, Tsubouchi R, Qiao SL, Li WH, Murakami K and Yakochi T: Prooxidant activity of curcumin; copper-dependant formation of 8-hydroxy20 -deoxyguanosine in DNA and induction of apoptotic cell death. Toxicol In Vitro 16: 783-788, 2004.

42. Braña MF and Ramos A: Naphthalimides as anti-cancer agents: synthesis and biological activity. Curr Med Chem Anticancer Agents 1: 237-255, 2001. 